\title{
MisRePRESENTATION UNDER ENGLISH \\ CONTRACT LAW AND ITS COMPARISON \\ to Slovak Contract LaW
}

\author{
Lucia Š́rová \\ Faculty of Law, Comenius University in Bratislava, Slovakia \\ lucia.sirova@flaw.uniba.sk
}

ŠÍROVÁ, Lucia. Misrepresentation under English Contract Law and Its Comparison to Slovak Contract Law. International and Comparative Law Review, 2016, vol. 16, no. 2, pp. 197-208. DOI: 10.1515/iclr-2016-0024.

\begin{abstract}
Summary: The aim of this paper is to introduce and analyse the concept of misrepresentation under the English contract law. In this regard, the paper primarily deals with the distinction between a term and a representation, key elements of misrepresentation, types of misrepresentation and remedies available to misrepresentees once the misrepresentation has been established. Furthermore, the author subsequently also presents a brief analysis of the Slovak contract law in order to identify any statutory provisions which could be applied to situations where a contract governed by the Slovak law contains representations and outlines what remedies are eventually available in situations where such representations later turn out to be false.
\end{abstract}

Keywords: common law, contract law, representations, misrepresentation, fraudulent misrepresentation, innocent misrepresentation, negligent misrepresentation, rescission, damages

\section{Introduction}

According to the recent trends and developments in the area of contract law, a number of common law concepts have had to be dealt with lately by continental law countries as a result of ever growing globalisation. Representations and warranties ${ }^{1}$ have become a standard part of a number of international commercial contracts entered into also in the Slovak Republic especially due to lots of supranational companies and their business activities carried on in Slovakia.

1 The term "representations and warranties" is quite frequently incorporated in a number of commercial contracts in a way implying that the term "representation" means the same as the term "warranty". Actually, in the US legal terminology, these terms are currently used almost interchangeably, whereas in the UK a distinction is made between these two terms. For more information about this issue, see an article titled Representations and Warranties in Private $M \mho A$ at http://www.osborneclarke.com/connected-insights/blog/representations-and-warranties-in-private-mergers-and-acquisitions/ [seen on 7.9.2015]. For the purposes of this paper and given the limitation of its extent, we only deal with the concept of representations further on. 
They may be found incorporated in e.g. loan agreements, share purchase agreements, license agreement, sales agreements, etc. Representations and warranties stem from the English contract law and they do not correspond to the Slovak regulation of the concept similar to representations or warranties (such as the one contained in Section 429 of the Commercial Code 2 ). ${ }^{3}$

In this regard, we provide a brief insight into the English contract law where the concept of representations is very closely related to misrepresentation, i.e. providing false statements in order to induce the other party to enter into a contract. Misrepresentation is related to the period prior to the formation of the contract and can arise as a result of contracting parties' conduct. This concept recognized by the English contract law is not reflected in the Slovak law in the same way and one could only wonder how the Slovak contracting parties or Slovak courts ought to deal with it.

The purpose of this paper is to introduce and analyse the concept of misrepresentation as regulated by the English contract law and to compare it to the Slovak contract law and identify any possible statutory provisions under the Slovak Civil Code and Commercial Code which could be applied to a situation where a contract governed by the Slovak law contains various representations which turn out to be false and thus cause damage to one of the contracting parties.

\section{Representations under English Contract Law}

Contracting parties and eventually the judges as well have to be able to ascertain whether a statement made by one party to the other party before a contract is formed has been incorporated into such contract as a representation. Such statement can possibly also be incorporated into a contract as a term and this difference could be significant especially due to different remedial consequences.

A representation is defined as a statement made by one of the two contracting parties to the other before or at the time of making the contract, in regard to some fact, circumstance, or state of facts pertinent to the contract, which is influential in bringing about the agreement. ${ }^{4}$ To put it simply, a representation as a statement is made in order to motivate the other contracting party to enter into the contract. Representations are not considered to represent contractual stipu-

2 Act No. 513/1991 Coll. (Commercial Code) as subsequently amended.

3 For more information about representations and warranties and their impact on the Slovak contract law, see also: FERTALOVÁ, Alžbeta. Prehlásenia a záruky (Representations and Warranties) a ich význam v obchodných zmluvách. In Obchodné záväzky: V̌seobecná čast. Zborník z III. študentského sympózia $z$ obchodného práva. Košice: Univerzita Pavla Jozefa Šafárika v Košiciach, 2016, pp. 58-65. and also GYÂRFÁŠ, Juraj. Inštitút "representations and warranties" v slovenskom práve. In Bulletin slovenskej advokácie, 2013, vol. 19, no. 3, pp. 26-35.

4 Definition available online at: < http://thelawdictionary.org/representation/> 
lations in their true sense; they merely confirm the fact that a contracting party provided these statements during the formation of pre-contractual relationships.

A term, on the other hand, is defined as any provision which forms part of a contract. ${ }^{5}$ In order to have a clearer picture of the distinction between a representation and a term, we refer to a statement presented by some authors who described terms as "being part of the contract" while representations only "floating around the edge of the contractual relationship but being outside its borders and not forming part of the contract."

However, it is still rather complicated to determine whether the statement is a representation or a term of the contract. A number of tests are used by the English courts to distinguish a term from a representation since it is not possible to recognise a term from a representation only by looking at the words used by the contracting parties.

Generally, it has been established that one has to look at the circumstances and ask what a reasonable person would normally think of a particular statement in its overall context. Let us illustrate this fact by providing two similar cases with different outcomes. In spite of the fact that these cases are not quite up-to-date, they provide a very good insight into this issue.

In Oscar Chess Ltd v Williams (1957)7, a car was sold by Mr Williams to Oscar Chess Ltd which was a dealer. Mr Williams stated that the car was a 1948 model according to the registration book. However, the car was in fact a 1939 model and therefore its price was much lower. The dealers therefore claimed the difference in value as damages for the breach of contract. The judge applied the so-called objective test of intention in deciding the case and stated that Mr Williams was not in a position where he should have known the true facts - he relied on the information set out in the registration book which turned out to be misleading so the statement was classified as a representation. The car dealer had a greater knowledge and would be in a better position to know the age of manufacture than the defendant (Mr Williams). Furthermore, the judge also noted in this regard that if a contract is later written down, it is very probable that any oral statements repeated in the written contract are intended to represent contractual terms and any statements which are omitted are likely to represent representations since the parties are likely to record only those statements which they want to form part of the contract. However, this is not an absolute rule which could always be applied.

5 MARTIN, Elizabeth A. (ed). Oxford Dictionary of Law. Sixth edition. New York: Oxford University Press, p. 545.

6 TAYLOR, Richard, TAYLOR, Damian. Contract Law. New York: Oxford University Press, 2013, p. 96.

7 See the whole case at: <https://cases.legal/en/act-uk2-43.html> 
On the other hand, in Dick Bentley Productions Ltd v Harold Smith (Motors) Ltd $(1965)^{8}$ where the dealers Harold Smith (Motors) sold a car to Dick Bentley Productions Ltd while stating that the car had done 20,000 miles (as originally shown on an odometer which later turned out to be incorrect information), the court ruled that under such circumstances the dealer was in a position to know or at least find out the true mileage and thus concluded that such statement was intended to be a term not a representation.

Differences between terms and representations are especially crucial as to remedial consequences. If a statement has been incorporated as a term and the person fails to comply with the statement, then there is an automatic right to damages for the breach of contract. In the event that the statement has not been incorporated as a term but as a representation, there is not an automatic right to damages if the representation turns out to be untrue. ${ }^{9}$ A false statement being a representation in respect of the contract may entitle the innocent party to damages (if there is a fault) but the usual remedy is to rescind the contract. However, even this remedy could be lost under specific circumstances.

In conclusion, the difference between a representation and a term of the contract is crucial especially as far as the available remedies are concerned.

\section{Misrepresentation under English Contract Law}

Once the concept of representations has been introduced, we can move onto the law of misrepresentation. English legal dictionaries define misrepresentation as an untrue statement of fact made by one party to the other in the course of negotiating a contract that induces the other party to enter into the contract. ${ }^{10}$ Misrepresentation thus actually refers to the fact that one "has been had", i.e. misled into a contract by the other contracting party which provided a false statement.

Misrepresentation arises within the period prior to the formation of the contract during negotiations which are held between the contracting parties. The English law does not recognise any positive duty to negotiate in good faith and instead imposes a negative duty upon contracting parties not to make false statements of fact to each other which would induce the other party to enter into the contract.

8 See STONE, Richard, CUNNINGTON, Ralph. Text, Cases and Materials on Contract Law. Oxon: Routledge-Cavendish, 2007, p. 366.

9 In the past, before the Misrepresentation Act 1967 was passed in the UK and before the decision of the House of Lords in Hedley Byrne \& Co Ltd v Heller \& Partners [1964] AC 465 , damages could only be recovered for the fraudulent misrepresentations under the English contract law.

10 MARTIN, Elizabeth A. (ed). Oxford Dictionary of Law. Sixth edition. New York: Oxford University Press, 2008, p. 354. 
The law of misrepresentation is seen as rather complicated due to the fact that it occupies the boundary between a contract, tort and unjust enrichment. In fact, misrepresentation falls more naturally in the territory regulated by the law of torts and thus questions which arise more usually in the law of torts (whether misrepresentation was made fraudulently or negligently) are crucial in deciding whether there should be any compensation. However, its effects on contracts are definitely an important part of the law of contracts and have significant consequences for the contracting parties. We comment on and deal with these consequences further below.

The English contract law currently distinguishes between fraudulent, negligent and innocent misrepresentation. ${ }^{11}$ The fraudulent misrepresentation is established when a person makes a false statement which he knows is not true and has no belief in its truth or which he makes recklessly not caring whether it is true or not. ${ }^{12}$ In other words or to put it simply, in order to sue someone for fraudulent misrepresentation, you have to prove that the person knew he or she was lying, or said something that he or she was not technically sure was a lie, but he or she had no reason to believe it was true. Moreover, another important element constituting the fraudulent misrepresentation is the fact that the misrepresentation is material to the transaction in question, i.e. it must be made in connection with the transaction and the person must be intentionally trying to affect the transaction with such lie.

The negligent misrepresentation is established when a false statement is made by the person which the person may honestly believe to be true but without reasonable grounds for believing it to be true. This class of misrepresentation is stipulated in Section 2(1) of the Misrepresentation Act 1967 and the burden of proof is on the representor to demonstrate he had reasonable grounds for believing the statement to be true. An example of the negligent misrepresentation is a situation in which a salesman claims that a cell phone that he is trying to sell has specific features without knowing if it does or not. He would be liable for committing negligent misrepresentation if the plaintiff was harmed by the misleading fact.

The last one of the three recognized types of misrepresentation is the innocent misrepresentation which is the one which the representor honestly believed to be true and he can demonstrate reasonable grounds for belief in the truth of the statement. Apart from the elements necessary to constitute the negligent and fraudulent misrepresentation, there is a special element unique for the innocent

11 However, the law of misrepresentation underwent a number of significant changes in the past. In particular, there were only two main categories of misrepresentation, fraudulent and innocent, until the 1960s. The concept of the negligent misrepresentation was introduced later, around 1964.

12 The definition of this class of misrepresentation was provided in Derry v Peek [1889] by Lord Herschell. To read a brief summary of the case, see MARTIN, Jaqueline, TURNER, Chris. Contract Law, Key Cases. Oxon: Bookpoint, 2006, p. 76-77. 
misrepresentation - if the misrepresentation made does not benefit the person who made it, or hurts both parties to the contract, it will not be considered a case of misrepresentation by the courts.

In order to ascertain whether misrepresentation arose or not, one has to firstly carefully examine the nature of representation and determine on what grounds it becomes actionable due to its falseness. The English case law has established several approaches in this regard to which we point in a rather brief way further below. It was ruled that unambiguous statements of fact can be actionable as misrepresentation unlike the statements of intention which cannot constitute actionable misrepresentation unless such statement of intention carries with it an implied statement of fact as to the state of mind of the representor. ${ }^{13}$ In terms of an opinion, a mere statement of it does not represent actionable misrepresentation. ${ }^{14}$ However, a statement of opinion can give rise to actionable misrepresentation provided that it is contradicted by other facts known to the representor. On the other hand, it was also ruled that a statement of opinion will not be actionable if the representee did not have reasonable grounds to rely on the representor's opinion. The courts also dealt with the issue of a false statement of law and whether this might constitute an actionable misrepresentation which eventually led to several contradictory decisions since the courts had difficulties in distinguishing between representations of law and representations of fact. Previously, it had been thought that a false statement of law was not actionable as a misrepresentation but this traditional rule was questioned by the decision of the House of Lords in Kleinwort Benson v Lincoln City Council [1999]. What about being silent and not making any statements at all? What implications could such situation have? The general rule is that there is no misrepresentation by silence since no duty to disclose material facts is recognised by the English law. However, there are several exceptions to this general rule.

In spite of the fact that nothing has been said, the misrepresentation might also originate from a conduct of a contracting party. ${ }^{15}$

Furthermore, apart from the nature of representation, it is also necessary to refer to another key element of misrepresentation which the claimant is also

13 See e.g. Curtis v Chemical Cleaning \& Dyeing [1951], a case in which it was established that unambiguous statements of facts are actionable as misrepresentation and e.g. Edgington $v$ Fitzmaurice (1885), a case in which the directors of a company issued a prospectus inviting subscriptions for debentures and such prospectus stated that it was intended to use the money obtained to make improvements in the company by altering buildings, purchasing horses and vans, etc. However, the real intention was to use the money obtained to pay off existing debts of the company. Therefore, the Court of Appeal held that the statement of intention was misrepresentation of fact as to the state of mind of the directors since there had never been an intention to use the money in the manner stated.

14 See e.g. Bisset $v$ Wilkinson [1927]

15 One of the notorious cases in this regard is Spice Girls Ltd $v$ Aprilia World Services BV [2002]. 
required to show -representation must have been material which means that it would have induced a reasonable person to enter into a contract. In order to demonstrate that representation induced the representee to enter into the contract, the claimant would have to show that representation was known to the representee, intended to be acted on and actually acted on. All of these requirements have to be met cumulatively. ${ }^{16}$

\section{Remedies Available for Misrepresentation}

The protection against false representations has increased considerably during the last third of the twentieth century. Remedies awarded in cases of misrepresentation differ depending on the type of misrepresentation - one has to distinguish between fraudulent, negligent and innocent misrepresentation as it has already been pointed out. Before outlining these distinctions, we have to say that for any misrepresentation, the remedy of rescission is in principle available. Rescission is defined as setting aside of a voidable contract which is thereby treated as if it had never existed ${ }^{17}$. In addition to rescission, other remedies are available as well depending on the type of misrepresentation.

Originally, rescission was only available for fraudulent misrepresentation in the past. However, equity extended this right to all categories of misrepresentation and therefore any type of misrepresentation renders a contract voidable - the misled representee is given the option to either set the contract aside or, alternatively, to affirm it. In case the contracting party decides to rescind the contract, it will be set aside retrospectively and prospectively. The aim of this remedy is to put the contracting parties in their original position as though the contract had not been made - the contracting parties will thus be restored so far as it is possible to their pre-contractual positions. ${ }^{18}$

The injured party may rescind the contract by notifying the representor that he or she intends to rescind the contract but this is not always necessary as any act indicating the rescission (notifying the court) may suffice.

However, there are certain limitations with respect to the right to rescind the contract and the injured party may thus lose this right under certain circumstances. There are four situations in which the right of the injured party to rescind the contract is lost: (i) the injured party affirms the contract - with the full knowledge of misrepresentation and of the right to rescind the contract, the party expressly states that it intends to continue with the contract (or the party does an act from which such intention may be implied); (ii) the injured party does not take any action to rescind the contract within a reasonable time; (iii)

16 See e.g. Horsfall $v$ Thomas (1862), Peek v Gurney (1873), Atwood v Small (1838).

17 MARTIN, Elizabeth A. (ed). Oxford Dictionary of Law. Sixth edition. New York: Oxford University Press, 2008, p. 473.

18 We shall also note in this regard that before the Misrepresentation Act 1967 was adopted, rescission was not available where the contract had been performed. 
in case a substantial restoration is impossible - if the parties cannot be restored to their original positions and (iv) if a third party acquires rights in property in good faith and for value.

In addition to or as an alternative to rescission, damages for misrepresentation may be claimed and awarded as well. In case of fraudulent misrepresentation, the remedies available are rescission and damages in the tort of deceit unlike in the case of the negligent misrepresentation where the remedies available are damages in tort for negligent misstatement and rescission. As for the innocent misrepresentation, the remedy is either rescission with an indemnity or damages in lieu of rescission under the court discretion.

\section{Slovak Contract Law and the Ways It Could Deal with Misrepresenta- tion}

Given the fact that a number of contracts governed by the Slovak law frequently contain representations (and warranties), it is inevitable to determine how the Slovak law should deal with such representations provided that they turn out to be false and thus cause damage or harm to the relevant contracting party. These representations may concern both the contracting party as well as the subject matter of a contract.

In order to identify the relevant Slovak statutory regulation which would deal with providing false statements prior to concluding a contract, we analysed the statutory regulation contained in the Civil Code and Commercial Code and attempted to identify any provisions which would bear a resemblance to the English concept of misrepresentation. There are several situations which could be actually taken into account and which have also been presented by several legal practitioners dealing with these issues. ${ }^{19}$

Firstly, having studied the Slovak Civil Code ${ }^{20}$ which represents one of the most significant sources of law regulating the contract law, we could claim that provisions which bear a resemblance to the English concept of misrepresentation are the ones contained in Section 49a of the Civil Code under which a legal act shall be voidable if such act is performed by a person erroneously and such error arises from a fact which is decisive for the performance of such legal act and the person to whom such legal act was addressed gave rise to such error or must have known about it. A legal act shall also be voidable if the error was given rise to by such person deliberately. Under the Slovak contract law the error may

19 See e.g. FERTALOVÁ, Alžbeta. Prehlásenia a záruky (Representations and Warranties) a ich význam v obchodných zmluvách. In Obchodné záväzky: V̌seobecná čast'. Zborník $z$ III. študentského sympózia $z$ obchodného práva. Košice: Univerzita Pavla Jozefa Šafárika v Košiciach, 2016, pp. 58-65. and also GYÁRFÁŠ, Juraj. Inštitút "representations and warranties" v slovenskom práve. In Bulletin slovenskej advokácie, 2013, vol. 19, no. 3, pp. 26-35.

20 Act No. 40/1964 Coll. (Civil Code) as subsequently amended. 
lie in the reason for which the legal act is formed, in the subject matter of legal act, parties to legal act or in other circumstances in the absence of which such legal act would have never been performed. As it is obvious from the respective statutory provisions, the error is relevant as far as the legal consequences are concerned only in those situations where a contracting party is involved in causing the error, e.g. causing such error directly or in a situation where although it does not cause such error directly, it must know about such error in consideration of all circumstances. In analysing the concept of error under the Slovak law further, the Slovak regulation thereof stipulates that not every single error which has been made may lead to a voidable legal act. Generally, only a "material error" is of legal relevance, i.e. an error related to the nature of the legal act itself. However, in the event that an error is caused by the contracting party with a malicious intention, the fact whether the error is material or immaterial is not important - even an immaterial error is of a legal relevance. Apart from the voidability of legal act, one may also seek damages as a remedy available in the event that all general conditions under which the liability for damage arises are met. However, given the aforementioned, such approach could be rather complicated since it is believed that representations may not be directly considered as a legal act performed by a contracting party under the Slovak law since the nature of a representation does not meet the statutory definition of a legal act according to Section 34 of the Civil Code.

Secondly, some legal practitioners opine that once representations (and warranties) are regarded as an individual contractual relationship, their truth should be regarded as a contractual obligation, i.e. term, and their falseness (misrepresentation) should give rise to a claim for compensation under Section 373 of the Commercial Code (everybody who breaches his obligation arising from a contractual relationship is obliged to compensate the other contracting party for damage which such party suffers unless he is able to show that the breach of such obligation was caused by circumstances exempting one from the liability) or possibly under Section 420 of the Civil Code (everybody shall be held liable for damage which he caused by breaching his legal obligation). In this regard, contracting parties very often tend to incorporate into their contracts provisions such as "the falseness of representations (misrepresentations) is deemed to represent the breach of terms by the contracting party" However, such approach can be rather problematic as well given the provisions of Section 494 of the Civil Code pursuant to which an obligation in general means that one has to give something, act in a particular way, refrain from doing something or tolerate something done to him. Furthermore, such approach does neither correspond to the English concept of misrepresentation law which emphasizes the distinction between a term and a representation.

Thirdly, several opinions presented in this regard point out the fact that once a contracting party provides certain representations in e.g. a sales agreement, such 
representations could correspond to and be regarded as the qualities of the thing subject to the sale which the parties agreed upon and which should thus be binding. It is a situation in which e.g. the seller declares that the thing which the buyer intends to purchase has particular qualities, i.e. is of a particular nature, usually the one requested by the buyer. Therefore, in the event that they turn out to be untrue and false (in the event of misrepresentation) such conduct could give rise to the liability for defects. The general statutory regulation of liability for defects is contained in Section 422 et seq. of the Commercial Code stating, inter alia, that the seller is obliged to deliver the goods in the quantity, quality and design which has been agreed upon in a contract and in the event that the seller fails to comply with such requirements, the goods are defective. Furthermore, these provisions also deal with legal defects of goods stating that such legal defects arise where the goods are encumbered with third party's rights. These provisions also state that should the delivered defective goods amount to a substantial breach of contract, the buyer shall have several remedial options, including (i) removal of defects by replacement, provision of missing goods or removal of legal defects, (ii) repair of defective goods provided that such repair is possible, (iii) reasonably discounted purchase price or (iv) rescission. In terms of the statutory provisions dealing with the liability for defects contained in the Commercial Code, we should also refer to Section 486 of the Commercial Code dealing with the liability for defects in case of the transfer of undertaking. The relevant general statutory regulation of liability for defects contained in the Civil Code may be found in Section $499 \mathrm{et}$ seq. stating, inter alia, that everybody who gives a thing in exchange for payment, shall ensure that such thing is of a desired nature and such thing may be used in accordance with the character and purpose of a contract or in accordance with what has been agreed upon by the contracting parties and furthermore, he shall ensure that there are no legal defects in the thing. In the event that such defect may not be removed and the thing may not be used in the way agreed upon, the injured party shall have a right to seek rescission. Otherwise, the party shall have a right to seek the reasonably discounted purchase price, exchange of defective goods or their repair. In addition to the foregoing provision, Section 596 et seq. of the Civil Code also deals with the liability for defects in connection with a purchase contract. Under these provisions, in negotiating a purchase contract, the seller is obliged to notify the buyer of the defects in the things he knows about. In the event that a defect arises later on, without the seller having previously warned the buyer about such defect, the buyer is firstly entitled to a reasonably discounted price and in the event that such defect may not be removed, the buyer shall have a right to rescind the contract. Furthermore, the buyer shall have a right to rescind the contract also where the seller assured the buyer that the thing was of a certain quality, in particular the quality which the buyer desired, or the seller assured the buyer that such thing was not defective but such statement turned out to be false. 
In addition to the foregoing approaches, we could also refer to provisions stipulated in Section 45(1) of the Commercial Code dealing with the so called deceptive advertising which means advertising goods, services, real property, trade name, trademark and other rights and obligations which is or may be misleading for persons for whom it is intended and which, due to its deceptive nature, may affect the economic behaviour of these persons or which is or may be detrimental to other competitors or consumers. In terms of remedies available to parties whose rights were violated or endangered through deceptive advertising, the injured parties may request that the other party refrains from such conduct or compensates them (even monetarily) or sue on the grounds of unjust enrichment.

\section{Conclusion}

Under the English law, misrepresentation has been developing as an individual area of law with a very specific position in the contract law. Misrepresentation is, in fact, a tort, a civil wrong, which has its statutory regulation contained in the Misrepresentation Act and the character of which has also been significantly shaped by the relevant case law. Once established, misrepresentation leads to a number of remedial consequences which are important for the contracting parties and the contracts they entered into and it is therefore also very important to differentiate between a representation and a term in a contract.

As it has been pointed out in this paper, representations have also been frequently incorporated into a number of commercial contracts governed by the Slovak law and have thus led to uncertainty as to their interpretation in case they turn out to be false since such concept is not regulated and recognised by the Slovak law in the same way. Legal practitioners have been trying to solve this issue by referring to and applying various statutory provisions contained either in the Civil Code or Commercial Code (depending on the nature of contractual relationship at issue) which bear the greatest resemblance to them.

No uniform approach has been adopted so far since one has to assess every particular situation individually and differently. In this respect, it is always extremely important for any contracting party entering into a contract governed by the Slovak law and containing representations to clearly and unambiguously stipulate what implications the misrepresentation has for the contracting parties - what obligations it constitutes and imposes on the misrepresentor - in order to avoid any uncertainty in their interpretation and remedial consequences.

We also believe that the Slovak case law will be more developed in the future and will provide a more useful guidance on how to deal with this issue since the number of contracts containing representations will most likely increase. Moreover, one could possibly propose a certain statutory development in the area of 
ICLR, 2016, Vol. 16, No. 2.

the Slovak contract law which would reflect the given issue in a particular way and provide an answer to numerous questions arising in this regard. 